\title{
A hagyományos, a helyi és a bennszülött tudás az IPBES Globális, illetve Európa és Közép-Ázsia értékelő tanulmányában
}

\author{
Molnár Zsolt , Babai Dániel², Varga Anna ${ }^{1}$, Demeter László ${ }^{1}$ és \\ Öllerer Kinga ${ }^{1,3}$ \\ ${ }^{1}$ MTA Ökológiai Kutatóközpont, 2163 Vácrátót, Alkotmány u. 2-4. \\ ${ }^{2}$ MTA Bölcsészettudományi Kutatóközpont, 1097 Budapest, Tóth Kálmán u. 4. \\ ${ }^{3}$ Biológiai Intézet, Román Akadémia, 060031 \\ Bukarest, Spl. Independenței 296., Románia \\ E-mail:molnar.zsolt@okologia.mta.hu
}

\begin{abstract}
Összefoglaló: A Biológiai Sokféleség és az Ökoszisztéma-szolgáltatások Globális Értékelő Tanulmánya, amelyet az ENSZ Biológiai Sokféleség és Ökoszisztéma-szolgáltatás Kormányközi Testülete (IPBES) jelentetett meg 2019 májusában, elismerte, hogy a természet védelme hatékonyabbá válhat a hagyományos, bennszülött és helyi tudás bevonásával, illetve ezen tudás birtokosainak részvételével. Jelen tanulmány azokat a rendelkezésre álló tudományos eredményeket és legfontosabb üzeneteket foglalja össze, amelyek ezt az állítást alátámasztják. Az eredeti idézeteket (dölt betüvel) a Globális és az Európa és Közép-Ázsia Értékelő Tanulmány döntéshozók számára készített összefoglalójából és az értékelő tanulmányból válogattuk össze, hogy bemutassuk, milyen következtetésekre jutottak a szerzők a tudományos és az ún. hagyományos tudás elérhető legjobb szakirodalmának értékelése során. Az eredeti szövegekhez kapcsolódóan néhány regionális (közép- és kelet-európai) vonatkozást is megemlítünk.
\end{abstract}

Kulcsszavak: hagyományos ökológiai tudás, hagyományos tájhasználat, tudásrendszerek, közös tudásalkotás

„Ez olyan, mint az otthon, ezt nem lehet elmondani. Ezt érezni kell! Tavasszal, mán az ember mikor kimegy, beleszagol a friss levegöbe, azt nem lehet elmondani azt az érzést, hogy milyen." (Barta Sándor, gulyás, in Kis et al. 2017, az Európa és Közép-Ázsiai Értékelő Tanulmány 2. fejezetének nyitóidézete, Martín-López et al. 2018). 


\section{Bevezetés}

Az ENSZ Biológiai Sokféleséggel és Ökoszisztéma-szolgáltatással foglalkozó Kormányközi Testülete (IPBES, http1) 2019 májusában közzétette a Biológiai Sokféleség és Ökoszisztéma-szolgáltatások Globális Értékelő Tanulmányát (IPBES 2019a, b). Ezek az IPBES értékelések az első olyan globális és regionális összefoglalók, amelyek nemcsak a természet- és társadalomtudományok eredményeit használják, hanem a bennszülött és a helyi közösségek ún. helyi és hagyományos ökológiai tudására is erősen támaszkodnak. Ezek az értékelések azt állítják, hogy a bennszülött népek és a helyi közösségek (angol kifejezéssel: Indigenous Peoples and local communities) tudásrendszerei és hagyományos extenzív tájhasználati módjaik gyakran aktívan és pozitívan járulnak hozzá a biológiai sokféleséghez és annak megőrzéséhez, emellett segíthetnek megváltoztatni magatartásunkat és elmozdulni természeti örökségünk és erőforrásaink fenntarthatóbb használata felé (Díaz et al. 2018, Molnár 2018). Ebben a cikkben összefoglaljuk a Globális Értékelő Tanulmány (GA, IPBES 2019a, b), az Európa és Közép-Ázsia Regionális Értékelő Tanulmány (ECA, IPBES 2018a, b), illetve ezek, szempontunkból példaértékü fejezeteinek (Martín-López et al. 2018, Elbakidze et al. 2018, Purvis et al. 2019), valamint az Európa és Közép-Ázsia Értékelő Tanulmány Bennszülött és Helyi Tudás Párbeszéd-konferenciája tanulmánykötetének (Roué \& Molnár 2017) kulcsfontosságú üzeneteit, különös tekintettel azokra, amelyek a bennszülött és helyi közösségekkel, valamint az ő tudásukkal kapcsolatosak, és emellett közép- és kelet-európai jelentőségük is van. Fontos hangsúlyozni, hogy míg az értékeléseket a kutatókból álló szerzőgárda fogalmazta, a döntéshozóknak készült összefoglalót a plenáris ülés során a kormánydelegációk olykor lényegesen átfogalmazták, ezért a két dokumentum között kisebb eltérések keletkeztek (emiatt is jeleztük mindig, hogy az adott gondolat mely anyagból származik). A Marie Roué és Molnár Zsolt által szerkesztett konferenciakötet (Roué \& Molnár 2017) elsődleges célja az volt, hogy a tudomány emberei számára elérhetővé és idézhetővé tegyen olyan tényeket és következtetéseket, amelyek a bennszülött és helyi közösségekben közismert tudásnak számítanak, és jelentős mértékben hozzájárulhatnak az értékelések tudásrendszereken átívelö következtetéseihez.

E tanulmánynak több célja is van, emiatt szerkezete és stílusa részben eltér a Természetvédelmi Közleményekben szokásostól. Egyik fontos célunk az volt, hogy az eredeti IPBES gondolatok magyar fordításban is rendelkezésre álljanak a hazai olvasók és felhasználók számára. Az eredeti angol nyelvủ szövegrészek megtalálhatók a cikk angol változatában, jelen cikk függelékeként. A fordítás során igyekeztünk szöveghüek maradni, ugyanakkor a szöveg gördülékenysége és érthetősége érdekében ettől időnként el kellett kissé térni, illetve közbeszúrá- 
sokkal segítettük az olvasót a szöveg és a szakterminusok könnyebb, de pontos megértésében (szögletes zárójelben és álló betűvel). A cikk másik célja, hogy az IPBES-ben megfogalmazott gondolatokat közép-európai és legfóképp hazai kontextusba helyezzük, így is segítve az IPBES értékelő tanulmányok föbb eredményeinek és következtetéseinek hazai hasznosulását.

A Globális Értékelő Tanulmány (IPBES 2019a, b) röviden összefoglalja a természet helyzetét, változásainak irányát és mozgatórugóit, valamint a helyi megélhetésre gyakorolt hatásait a bennszülöttek és a helyi közösségek által kezelt és használt területeken: „A bennszülöttek és a helyi közösségek által használt természeti területekre egyre növekvő nyomás nehezedik. Bár általánosságban a természet lassabban pusztul a bennszülöttek által használt területeken, mint máshol, mégiscsak pusztul, csakúgy, mint a fenntartásához szükséges tudás. A világ szárazföldi területének legalább egynegyedén bennszülött népek élnek, gazdálkodnak. Ilyen területre esik a formálisan védett területek mintegy 35\%-a és az emberi beavatkozás által kevéssé érintett szárazföldi területek mintegy 35\%-a [lásd részletesebben: Garnett et al. 2018]. Továbbá, változatos tulajdonviszonyok és haszonvételi keretek között számos különbözö ún. helyi közösség, beleértve földmüveseket, halászokat, pásztorokat, vadászokat, állattartók és erdögazdálkodók, is jelentös területeken gazdálkodik a természettel. A bennszülött és helyi közösségek által kifejlesztett és használt, a természet helyi állapotát monitorozó indikátorok közül 72\% negativ tendenciát mutat a helyi megélhetés és a jóllét [életminőség] alapját biztositó természeti elemek kapcsán [lásd részletesebben: Purvis et al. 2019]. A bennszülött és helyi közösségek által (különféle tulajdonviszonyok, bérleti és haszonvételi keretek között) használt területeket növekvö mértékben terheli a nyersanyag-kitermelés, árutermelés, bányászat, valamint a közlekedési és energetikai infrastruktúra, és ez számos [részben negatív, részben pozitív] következménnyel jár a helyi megélhetés és egészség tekintetében. Néhány, az éghajlatváltozást csökkenteni szándékozó programnak [pl. erdősítések, energianövényültetvények] is káros hatása van a bennszülött népekre és a helyi közösségekre [pl. a helyi élelmiszertermelés elöl területeket foglal el]. [A helyi közösségek által használt területeket terhelö] tevékenységek negatív következményei közé tartozik a hagyományos megélhetési formák ellehetetlenülése a folyamatos erdöirtás, a vizes élöhelyek elvesztése, a bányászat, a fenntarthatatlan mezögazdasági, erdögazdálkodási és halászati módok terjedése miatt, valamint a környezetszennyezés és a vizellátás bizonytalansága miatt, mindezek kihatnak az egészségre és az egyéni és társadalmi jólétre. Ezek a negatív hatások sokféle kihivást jelentenek a bennszülött népek és a helyi közösségek hagyományos gazdálkodása, a bennszülött és a helyi tudás átadása, valamint a vadon élö és háziasitott fajok és fajták e 
közösségek általi védelme és fenntartható használata kapcsán is. Továbbá azon hasznok megosztása szempontjából is, amelyek e fajok és fajták használatából származnak, és amelyek a szélesebb társadalom számára is nagy fontossággal birnak" (IPBES 2019a).

A Globális Értékelő Tanulmány szerzői hangsúlyozzák, hogy „számos hagyományos tájhasználati mód aktivian és pozitivan járul hozzá a vadon élö fajok és háziasitott fajták sokféleségéhez azáltal, hogy a természetes folyamatokat antropogén eszközökkel (tudás, tapasztalat és technológia) segitik, «kísérik». A bennszülött népek gyakran kulturálisan sajátos világnézetek alapján gazdálkodnak a szárazföldi és tengerparti területeken. Olyan elveket és indikátorokat alkalmaznak, mint a táj egészsége, a területröl való gondoskodás és a kölcsönös felelösség [a természet és emberi közösség között]. [Megjegyezzük azonban, hogy] bizonyos régiókban a fenntarthatatlan gyakorlatok egyre gyakoribbá válnak a globalizáció miatt változó életmód, értékrend és külső nyomás hatására" (IPBES 2019a). Az alábbi lista célja, hogy a teljesség igénye nélkül bemutassa a bennszülött népek és a helyi közösségek hozzájárulásainak típusait és sokféleségét (további információ: IPBES 2019a):

- a helyi körülményekhez alkalmazkodó növény- és állatfajták háziasítása és fenntartása;

- fajgazdag élőhelyek és változatos ökoszisztémák létrehozása kultúrtájakban (pl. kaszálórétek, fáslegelők);

- hasznos növények beazonosítása és termesztése sokfajú agrár-ökoszisztémákban (pl. trópusi „erdő-kertek”);

- $\quad$ tájak, élőhelyek és vadon élő fajok kezelése és monitorozása a vadon élő élővilág és az ökológiai rendszerek rezilienciájának (rugalmas ellenállóképességének) növelése érdekében (pl. égetés az ausztrál bennszülötteknél);

- $\quad$ a degradált területek helyreállítása, restaurálása;

- az erdőirtás megakadályozása az államilag elismert bennszülött területeken (pl. Amazóniában); ezenkívül

- $\quad$ alternatív világnézeteket kínálnak az emberiség és a természet viszonyáról.

Mi a hagyományos tudás, és milyen szerepe van az örökségvédelemben, az identitásban és a fenntarthatóság elősegítésében?

„A bennszülött népek és a helyi közösségek sajátos tudással rendelkeznek a természetröl és a természet emberek számára nyújtott hozzájárulásairól [ez egy új, az ökoszisztéma-szolgáltatásokkal rokon, de annál tágabb fogalom, lásd Díaz et al. 2018], amelynek jelentös értéke van sok helyi közösség (IPBES 2018a, b)”, sőt az egész társadalom számára is. A Globális Értékelő Tanulmány szerint „A bennszülött és hagyományos tudás lokális jellegü, de hatása gyakran regionális léptékben nyilvánul meg, emiatt e tudásnak globális jelentösége van" (IPBES 2019a,b). 
Ez annyit jelent, hogy bár az egyes bennszülött és helyi közösségek viszonylag kis területre hatnak gazdálkodásukkal, e kis területek egész régiókká állhatnak össze (pl. az afrikai szavanna-övezet, az Amazonas-medence vagy a közép-ázsiai sztyeppék), és emiatt e sok-sok helyi közösség hatása globális jelentőségüvé válik, hiszen a Föld szárazföldjeinek több mint felét érinti (lásd Garnett et al. 2018).

Az IPBES a bennszülött és helyi tudás kifejezés alatt (ILK - Indigenous and Local Knowledge) adott helyhez kötődő - gyakran ökológiai jellegü - tudást, tapasztalatot és világnézetet ért, és azt állítja, hogy az ilyen tudás információt, módszereket, elméleti és gyakorlati segítséget nyújthat szellemi, fizikális és lelki síkon is a fenntartható ökoszisztéma-gazdálkodáshoz. A Biológiai Sokféleség Egyezmény (1992 óta) a hagyományos tudás (TK - Traditional Knowledge) vagy hagyományos ökológiai tudás (TEK - Traditional Ecological Knowledge) kifejezést használja. Ezen fogalmaknak sajnos nincs igazán pontos meghatározása, aminek történeti és politikai okai vannak, mert kiemelt szempont az inkluzivitás megtartása. Közép- és Kelet-Európa országaiban a bennszülött és helyi tudás (ILK), valamint a hagyományos ökológiai tudás (TEK) többé-kevésbé szinonimának tekinthető (Molnár et al. 2008, 2009), és az utóbbi fogalom használatát javasoljuk.

Európában széleskörü ismereteink vannak arról, hogy a helyi közösségek (a generációk óta extenzív táj- és vízgazdálkodást folytató, beállt, de adaptív hagyományt követő gazdálkodók, pásztorok és halászok) és az ő hagyományos (ökológiai) tudásuk és gyakorlataikon alapuló életmódjuk hogyan járult és járul hozzá a természeti és kulturális (azaz biokulturális) örökségünk kialakulásához és fennmaradásához (például, Gugič 2009, Fernández-Giménez \& Estaque 2012, Molnár 2012a, Bürgi et al. 2013, Babai et al. 2014, Hernández-Morcillo et al. 2014, Kis et al. 2017).

„Ugyanakkor sok, az ökoszisztémákat és fajokat érintő bennszülött és hagyományos tudás elveszett [azaz teljesen vagy részleteiben feledésbe merült, vagy jelentős mértékben átalakult]" (IPBES 2018a). Az Európa és Közép-Ázsia Értékelő Tanulmány szerzői (IPBES 2018a, b) szerint „,tudjuk, hogy Európában és Közép-Ázsiában [a tizennyolcból] hét ún. természeti hozzájárulás a jólléthez [vö. kb. ökoszisztéma-szolgáltatás] csökken, különösen a szabályozó hozzájárulások [pl. vízszabályozás, eróziógátlás] és a hagyományos tudás átadásából származó tanulás”, de emellett a mindennapi létfenntartáshoz is nélkülözhetetlen ,az élelemmel kapcsolatos bennszülött és helyi tudás is fogyatkozik'. A szerzők azt is hangsúlyozzák, hogy „kulturális örökségük gondozása és identitásuk megörzése révén a bennszülött és helyi közösségek tudása és hagyományos gyakorlatai az emberek életminőségét is javitják [pl. a biztonságérzetet és közösséghez való tartozást].” Megállapítják, hogy ,olyan robusztus és az érintetteket bevonó döntéshozatali folyamatokat kell kialakitani, amelyek lehetövé teszik, hogy a bennszülött 
és helyi közösségek tudása és a helyi viszonyokhoz igazitott gazdálkodási rendszereik beépithetök legyenek napjaink gazdálkodásába, és ezáltal hozzájárulhassanak a fenntarthatósághoz" (IPBES 2018a, b).

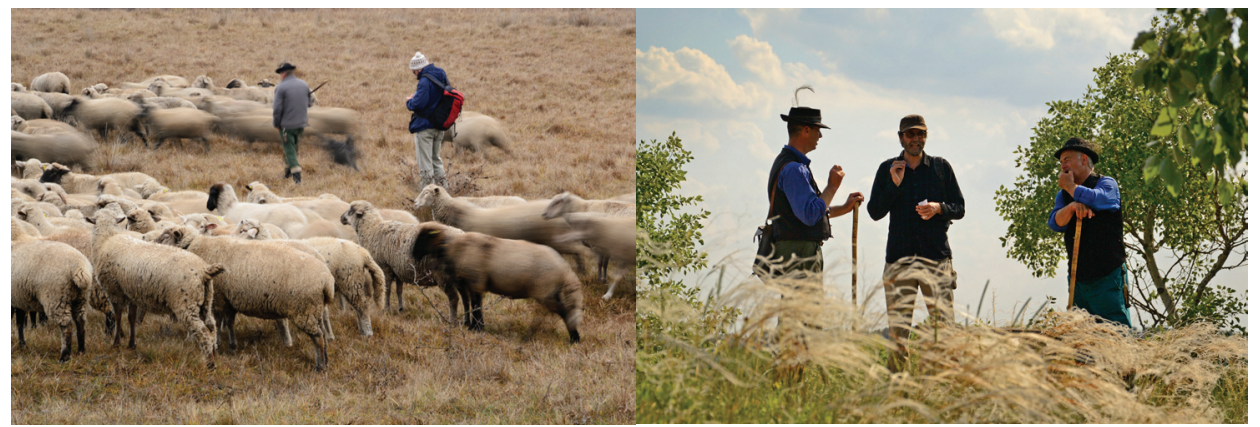

1. ábra: Közös tudásalkotás pásztorokkal (képek forrása: Molnár Ábel, Hajdúsámson, 2014, illetve Kunpeszér, 2016). Az IPBES Globális Értékelő Tanulmánya biológiai sokféleség és ökoszisztéma-szolgáltatások helyzetének és trendjeinek az első olyan, az egész bolygóra kiterjedő értékelése, amely a természettel szoros kapcsolatban élő és azt a megélhetésért sok generáció óta müvelő emberek ún. hagyományos, bennszülött és helyi tudásának tudatos bevonásával készült. A tapasztalat azt mutatja, hogy a gazdákkal és pásztorokkal végzett közös tudásalkotás hatékony módja a helyhez igazodó, kulturális és ökológiai szempontból is megfelelő természetvédelmi kezelési rendszerek kialakításának (Molnár \& Kovács 2014, Babai et al. 2015, Molnár et al. 2016, Varga et al. 2016a, Kovács et al. 2017).

\section{A fenntarthatóságot, természetvédelmet és restaurációt elősegítő hagyományos tájgazdálkodás}

„Az [1970-es évek óta bekövetkezett] társadalmi-gazdasági változások és a tájhasználat intenzifikációja következtében számos európai és közép-ázsiai térségben jelentösen csökkentek azok a területek, amelyeken még ma is hagyományos módon gazdálkodnak (Rotherham 2007). A mezögazdasági szempontból peremterületeken [pl. magashegységek, szikes és homoki területek], a természetvédelmi területeken vagy különféle társadalmi és kulturális preferenciák [pl. a hagyományokhoz való ragaszkodás, biogazdálkodás] következményeként mégis sokféle gazdálkodási mód fennmaradt (Juler 2014, Lieskovský et al. 2014, Molnár et al. 2016)." „A termelés-alapú [az intenzív termelést ösztönző] támogatások növekedést váltottak ki a mezögazdaságban, erdögazdálkodásban és a természeti erőforrások kihasználásában, de ez gyakran ütközik a tájban hagyományosan gazdálkodók érdekeivel [azaz elveikkel, értékrendjükkel, gyakorlatukkal]. A hagyományosan kezelt természetközeli élőhelyek elvesztése a hozzájuk kapcsolódó biológiai sokféleség és az ökoszisztéma-funkciók csökkenését és elvesztését eredményezte. A demográfiai trendek, többek között az urbanizáció miatt folyamatosan csökken 
a bennszülött és helyi közösségek lélekszáma, ami együtt jár a hagyományos tájhasználattal összefüggö tudást, kultúrát és identitást érintö kedvezötlen hatásokkal. Mindezen folyamatok a hagyományos tájhasználat felhagyását eredményezik, amely a nagy természetvédelmi értékü természetközeli területek degradációját és az azokhoz kötödö bennszülött és hagyományos tudás csökkenését is maga után vonja" (Elbakidze et al. 2018).

A helyi közösségek számos ilyen, a természetben, társadalomban és gazdálkodásban bekövetkezett változást kísérnek figyelemmel, monitoroznak (Molnár 2012c, Roué \& Molnár 2017, Reyes-García et al. 2019). Ennek ellenére az Európa és Közép-Ázsia Értékelő Tanulmány sajnos csak kevés információt tartalmaz arról, hogy a helyi közösségek hogyan érzékelik a biológiai sokféleség romlását az otthonukat jelentő tájban. A helyi hagyományos tudással rendelkező emberek és közösségek jövőképei, forgatókönyvei szintén hiányoznak az értékelésböl. Az IPBES értékelő tanulmányok tanulsága, hogy a kutatók és a helyi tudással bírók hatékony és etikus együttmüködése és a közös tudásalkotás nagy kihívás különösen azon kutatók számára, akik nem ismerik kellően a hagyományos tudásrendszerek és értékrendek sajátságait (Ulicsni et al. 2019). Ugyanakkor az IPBES értékelö tanulmányok mind regionális, mind globális szinten nagy előrelépést jelentenek a különböző tudásrendszerek összehangolása, a közös tudásalkotás és tudásszintézis terén.

A természetvédelemmel kapcsolatos konfliktusoknak hosszú története van. „Az európai és közép-ázsiai védett területek kialakitását vagy sikeres kezelését leginkább az befolyásolta, hogy hogyan tudták kezelni a helyi használat, illetve a védettség és a természetvédelmi kezelés között kialakuló konfliktusokat (Babai et al. 2015). A védett területek irányitására és gazdálkodási rendjére gyakran jellemzö a felülröl, ill. kívülröl való irányitás [top-down módszer], amelyben kismértékü vagy alacsony színvonalú a közösségi részvétel, a felelös hatóságok rugalmatlanok, és elégtelen a helyi körülmények figyelembe vétele, igy a természetvédelem megitélése kedvezötlen lesz, ellenállást váltva ki a helyi közösség tagjaiban (Blicharska et al. 2016, Carrus et al. 2005, Elbakidze et al. 2013, GrodzinskaJurczak \& Cent, 2011, Mathevet et al. 2016)" (Elbakidze et al. 2018). E konfliktusok közül sok elkerülhető vagy megoldható, ha nagyobb tudással rendelkezünk a helyi közösségekről, ökológiai tudásukról, illetve a természethez és a természetvédelemhez való hozzáállásukról (Kelemen et al. 2013, Kalóczkai et al. 2015, Molnár et al. 2016, Babai et al. 2017, Juhász et al. 2017, Kovács et al. 2017, Mihók et al. 2017).

„A természetvédelem és az extenziv tájhasználat egymásra utaltsága az elmúlt 20-30 évben vált nyilvánvalóvá. A kisléptékü, extenzív tájhasználat gyakran csak a védett területeken képes fennmaradni természetvédelmi kezelés formájában, a 
szabályozási keretrendszerekben [pl. az agrártámogatási rendszerekben] is általában a háttérbe szorul [bár vannak specifikus támogatások]. Az ilyen területek védelme érdekében hozott szabályozások gyakran egyáltalán nem veszik figyelembe a helyi közösség világnézetét vagy a helyi tájhasználat hatásait [bár vannak jó példák és előremutató szabályozások, Mihók et al. 2016, Molnár et al. 2016, Kovács et al. 2017]. Ez a helyi lakosság tevékenységének korlátozásához vezet (Babai et al. 2015, Molnár et al. 2016), és konfliktusokat okoz a helyiek és a védett területekért felelös hatóságok között (Kelemen et al. 2013). A helyi tájhasználati konfliktusok megoldása egy integráltabb, a helyi közösség közremüködésére, részvételére eröteljesebben épitö megközelités elfogadása lehet a védett területek irányitásában és kezelésében, különösen a helyi közösségek által birtokolt és/ vagy kezelt tájakban, illetve a kisparcellás gazdálkodásba vont kultúrtájakban. Olyan összekötö emberekre is szükség van, akik egyaránt ismerik a hagyományos gazdálkodási gyakorlatot és világnézetet, valamint a modern természetvédelmi elképzeléseket (Molnár et al. 2015). Emellett az agrár-környezetgazdálkodási programok [mint pl. az EU támogatási rendszere] bevezetése a védett természeti területeken lassithatja a hagyományos gazdálkodási módok eltünését, és ezzel megakadályozhatja a biológiai sokféleségnek a gazdálkodás felhagyásával járó csökkenését. Az egyik megközelités a helyi és hagyományos tudást is magába foglaló táj-és kultúraspecifikus mezögazdasági szabályozási keret és támogatási rendszer, amely adott lokalitásra szabott, egyedi megoldásokat kínál, tiszteletben tartva a természeti és kulturális 'tőke' közötti szoros kapcsolatot (Molnár \& Berkes 2017)" (Elbakidze et al. 2018).

\section{Hogyan segíthet a hagyományos tudás kezelési, gazdálkodási és szakpolitikai kérdésekben?}

Közép-Európa nemzeti parkjainak és más védett területeinek természetvédelmi kezelése a világ más területeivel összehasonlítva jól müködik (Mihók et al. 2017). Ugyanakkor még mindig sok a megoldásra váró probléma, tanulmányunk témájánál maradva, például hogy

- $\quad$ hogyan támogatható a kultúrtájak magas természeti értékü területeinek fenntartható használata;

- hogyan javítható a helyi közösségek megélhetése ezeken a területeken a biológiai sokféleség veszélyeztetése nélkül;

- hogyan használható a hagyományos tudás a természetvédelemben;

- $\quad$ hogyan ismerhető meg kellő mélységben a természettel kapcsolatos helyi tudás (pl. egy konkrét táj esetében lásd Molnár 2011a,b, 2012a,b,c, 2015), és hogyan akadályozható meg az elvesztése; 
- $\quad$ hogyan segíthető elő ennek a helyi tudásnak a továbbfejlesztése és adaptív alkalmazása a globális változások fényében; illetve

- hogyan javítható a kommunikáció, a bizalom és a tisztelet a természetvédelmi szakemberek és a helyi tájban még hagyományosan gazdálkodók (pl. parasztok, pásztorok) között (Agnoletti 2006, Fischer et al. 2012, Oteros-Rozas et al. 2013, Varga et al. 2016b, Demeter 2017, Molnár \& Berkes 2018, Biró et al. 2019, Reyes-García et al. 2019).

Az Európa és Közép-Ázsia Értékelő Tanulmány azt állítja, hogy „A 18. [Aichi Biodivezitás] célkitüzés [a Biológiai Sokféleség Egyezmény 2011-2020-ra kitüzött céljainak egyike] (a hagyományos tudás elismerése és védelme) ellenére az 1960-as évek óta a bennszülött és helyi közösségek természetismerete és gazdálkodási módja tovább hanyatlik Nyugat- és Közép-Európában, nem tartják öket tiszteletben, gazdasági és társadalmi szempontból is a perifériára szorulnak, ahogy tudásuk is” (IPBES 2018a, b). ,Miközben az EU Közös Agrárpolitikájának egyes eszközei támogatják az extenzív gazdálkodási módokat, eközben más szabályok kevésbé alkalmasak a magas természeti értékü mezögazdasági területeken a kisés részben önfenntartó gazdaságok hagyományos és helyi tudásának és gazdálkodási módjainak támogatására, illetve ezek nem megfelelöen valósulnak meg, különösen az EU közép-európai országaiban" (IPBES 2018a, b).

Az ECA szerzői azt is kijelentik, hogy „A bennszülött és helyi közösségek gazdasági életképességét a zöld turizmus, a hagyományos gazdálkodásból származó termékek iránti igény és a hagyományos tájhasználat anyagi támogatása is növelheti.” „Az agrár-környezetgazdálkodási programok, az ökológiai restauráció és a mezögazdaság fenntartható megközelitése, mint az agrárökológia és agrárerdészet, enyhitheti az intenzív mezögazdaság egyes negatív hatásait" (IPBES 2018a). Hozzátennénk, hogy a nagy tudással rendelkező helyi gazdák, pásztorok és halászok tisztelete és a természetvédelem számára kulcsfontosságú kérdésekben velük végzett közös tudásalkotás hatékonyan növelheti a helyi közösség jóllétét, illetve a tudásuk fennmaradását és a biológiai sokféleség fenntartható használata érdekében történő alkalmazását (Meuret \& Provenza 2014, Fabók et al. 2015, Kovács et al. 2016, Molnár et al. 2016, Varga et al. 2016a).

Az ECA szerzői megállapították továbbá, hogy „A részvételi tervezésen, a meglévö tudás jó 'menedzselésén'és kapacitásépitésen [megfelelö helyi szakemberek képzésén] alapuló végrehajtás (ez a 'E' Fenntartható Fejlödési Cél) sokkal hatékonyabb volt ott, ahol az Aichi Biodiverzitás Célokat beépitették a nemzeti szintü célokba [azaz az egyes országok saját Nemzeti Biodiverzitás Stratégiájába]. Ez azonban nem sikerült ott, ahol a bennszülött és helyi tudás és gyakorlatok eltüntek, vagy nem vették öket figyelembe a tájhasználattal kapcsolatosan" (IPBES 2018a). A tudással való gazdálkodásnak és a különböző szereplők bevonásának 
hatékony módja a helyi körülményekhez igazodó, adaptív és kulturálisan megfelelő biodiverzitás-gazdálkodási módok fenntartását, alkalmazását és kialakítását célzó közös tudásalkotás a természetvédők, helyi gazdák, pásztorok és halászok, illetve kutatók részvételével. A természetvédelmi örök - helyzetüknél fogva eredményesen tudják segíteni ezt a közös tudásalkotást (Varga et al. 2016a), és közremüködhetnek a tudomány és a helyi, hagyományos tudás közötti kölcsönös tanulásban (lásd a 'természetvédelmi pásztor' kifejezést, ami egy olyan pásztort jelent, aki mind a hagyományt, mind a modern természetvédelmet érti és műveli, Molnár et al. 2016). Az IPBES értékelő tanulmányok egyik legföbb célkitüzése, hogy a tudományos eredményeket és a hagyományos tudást egyaránt használja a biológiai sokféleség és a természeti hozzájárulások a jólléthez (vö. kb. ökoszisztéma-szolgáltatások) helyzetének és trendjeinek értékeléséhez (Díaz et al. 2018).

Az ECA szerzői szerint „az európai és közép-ázsiai országokban nagyon változó a biodiverzitás fenntartható használatával kapcsolatos emberi jogok, különösen a bennszülött népek jogainak elismerése. További eröfeszitések szükségesek az ún. 'jó kormányzás' alapelveinek teljes integrációja; a hatalmi viszonyok kiegyenlitése, valamint a kapacitásépités elösegitése érdekében" (IPBES 2018a). A természetvédelem jogalapú megközelítései (rights-based approaches), azaz a helyi közösségek emberi jogainak figyelembevétele a természetvédelmi intézkedések során, valamint a szokásjogok (pl. hagyományos szabályok, tabuk) elismerése és tiszteletben tartása (pl. közlegelők kapcsán) a legkevésbé kidolgozott és használt eszközkategóriát jelentik védett területek irányítása, kezelése során, ami tudáshiányt jelez, vagy talán az odafigyelés, sőt a bennszülött, hagyományos és helyi tudás és gyakorlatok elismerésének hiányát jelezheti. A szerzők hozzáteszik, hogy „, a bennszülött és hagyományos tudás csökkenése, és ezzel összefüggésben a fenntartható hagyományos tájhasználat hanyatlása veszélyezteti a régió hozzájárulását a 2. és a 4. [fenntarthatósági] cél teljesitéséhez (éhezés felszámolása és minöségi oktatás)” is. Hangsúlyozzák, hogy „támogatni és erösiteni kell a közösségi gazdálkodást és irányitást, beleértve a hagyományos közösségi intézményeket és irányitási rendszereket [pl. közlegelök, közbirtokosságok], valamint a bennszülött és helyi közösségeket is bevonó ún. közösen müködtetett kezelési-gazdálkodási [ún. co-management] rendszereket is" (IPBES 2018a, b). 


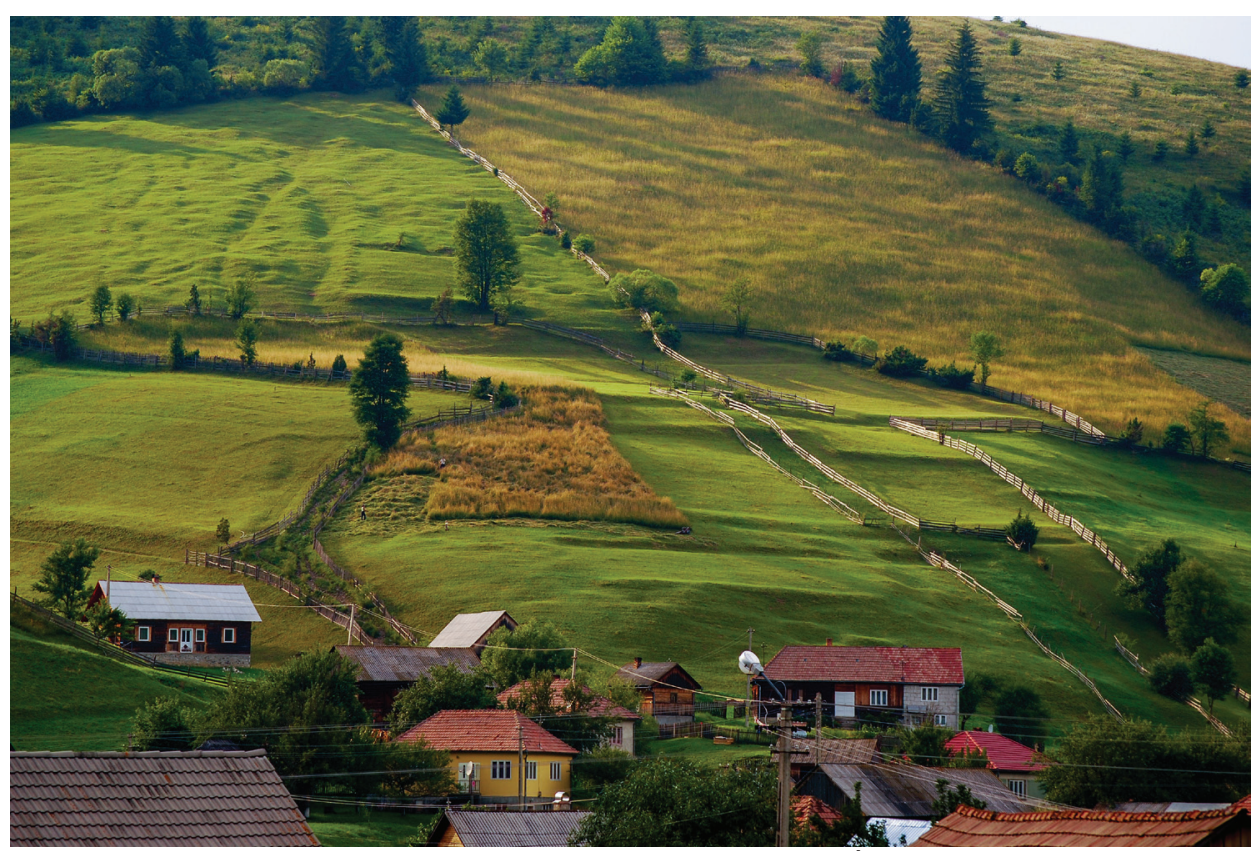

2. ábra: Fajgazdag kaszálórétek Gyimesben (kép forrása: Molnár Ábel, Gyimes, Románia, 2014). Az Európai Uniós és a nemzeti agrárszabályozások, valamint támogatások célja sokszor a hagyományos gazdálkodás támogatása a Natura 2000-es és egyéb védett természeti területek fajgazdag kultúrtájaiban. E szabályozások ugyanakkor károsak is lehetnek a helyi gazdálkodásra, ha azokat a helyi társadalmi-ökológiai körülmények tényleges megértése és a helyi gazdákkal végzett közös tudásalkotás nélkül dolgozzák ki, és tartatják be (Babai et al. 2015, Molnár et al. 2016).

\section{A kulcsfontosságú tudáshiányok}

Az Európa és Közép-Ázsia Értékelő Tanulmány nyolc tudáshiány-csoportot azonosított. Ezek közül kettő kifejezetten a hagyományos tudás fontosságát hangsúlyozza:

„Tudáshiány a bennszülött és a helyi tudás hozzájárulásának megértésében: kevés kutatást végeztek a bennszülött, hagyományos és helyi tudás nemzeti és nemzetközi szakpolitikai keretekbe történö integrációjával és a tudásrendszerek közötti szinergiák létrehozását célzó kezdeményezésekkel kapcsolatban. Ezek a tudáshiányok nemcsak a biológiai sokféleség kapcsán, hanem a biológiai sokféleséghez közvetlenül kapcsolódó ágazatokban is fennállnak, mint például a mezögazdaságban, az erdögazdálkodásban, a halászatban és a vizgazdálkodásban, továbbá az éghajlatváltozás kezelése kapcsán is" (IPBES 2018a, b).

„Tudáshiány a természet emberek számára nyújtott hozzájárulásainak megértésében: Szükség van az ember számára nyújtott természeti hozzájárulások változatos értékeinek jobb megértésére, számszerüsitésére és integrált vizsgálatára. 
Ráadásul keveset tudunk arról, hogy ezt a sokféle értéket a nök és férfiak, illetve a különbözö társadalmi csoportok mennyire érzik magukénak. A bennszülött, hagyományos és helyi tudásrendszerek és a tudományos tudás együttes alkalmazása jobb megértést tehet lehetövé." (IPBES 2018a, b).

\section{Miért számít mindez? Mi ennek a jelentősége?}

„A világ azon tájai, amelyeket az elörejelzések szerint súlyosan érintenek majd az éghajlat, a biológiai sokféleség, az ökoszisztéma-funkciók és a természet egyéni és társadalmi jólléthez biztositott hozzájárulásai terén tapasztalható globális változások, egyben nagyszámú bennszülött népnek és a világ legszegényebb közösségei közül is soknak adnak otthont. Mivel e közösségek nagymértékben függenek a létfenntartásuk, megélhetésük és egészségük alapját biztositó természettöl és annak a jólléthez biztositott hozzájárulásaitól, ezeket a közösségeket aránytalanul erösen fogják sújtani ezek a kedvezötlen változások. A kedvezötlen hatások a bennszülött népeknek és a helyi közösségeknek a vadon élö fajok és a háziasitott fajták sokfélesége, valamint a természet emberi jólléthez biztositott hozzájárulásai kezelésére és megörzésére való képességét is befolyásolják. A bennszülött népek és a helyi közösségek egymással és számos más érintettel együttmüködve, proaktivan néznek szembe ezekkel a kihívásokkal közös gazdálkodási rendszerek [co-management systems], valamint helyi és regionális monitoring-hálózataik segitségével, továbbá a helyi gazdálkodási rendszerek újjáélesztése és adaptiv alkalmazása révén. [Ennek ellenére] a regionális és globális forgatókönyvekben nem jelennek meg egyértelmüen a bennszülött népek és a helyi közösségek nézöpontjai, kilátásai és jogai, a nagyobb régiókat és ökoszisztémákat érintö tudásuk és ismereteik, valamint az általuk kivánt jövőbeli fejlesztési irányok" (IPBES 2019a, b).

Ezen túlmenően, a Globális Értékelő Tanulmány szerzői szerint ,a fenntarthatóság irányába mutató átalakulás valószinübb akkor, ha az eröfeszitések azokra a fö stratégiai pontokra irányulnak, ahol kiemelkedöen nagy hatás érhetö el." Ezek között a szerzők számos olyat sorolnak fel, amelyek közvetlenül kapcsolódnak a bennszülött és helyi közösségekhez, valamint gazdálkodási módjukhoz: „a helyi közösségekkel való együttmüködésre, bevonásukra alapuló, részvételi döntéshozatal biztositása”, ,, az emberi jogok tiszteletben tartása a természetvédelmi döntésekben”, „, az oktatás, a tudásalkotás és a különbözö tudásrendszerek fenntartásának támogatása, ideértve az akadémiai tudományokat és a természettel, a természetvédelemmel és a természet fenntartható használatával kapcsolatos bennszülött, hagyományos és helyi tudást is" (IPBES 2019a, b). 
„A bennszülött népek és helyi közösségek bevonása és részvétele a környezeti kérdésekkel kapcsolatos irányításba, valamint tudásuk, innovációik és gyakorlataik, intézményeik és értékeik elismerése gyakran javitja az életminöségüket, valamint elösegíti a természet védelmét, restaurálását és fenntartható használatát, amely a társadalom szélesebb köre számára is jelentöséggel bír. Ezentúl a bennszülött népek és helyi közösségek fenntarthatósághoz való pozitiv hozzájárulását elömozdíthatja a földtulajdonra, a földhasználatra és a természeti eröforrásokra vonatkozó jogok - nemzeti jogszabályoknak megfelelö - elismerése [az őket és területeiket érintő kérdésekben]; a szabad, elözetes tájékoztatáson alapuló jóváhagyás [az ún. Free Prior Informed Consent, FPIC] intézménye, valamint a szorosabb együttmüködés és a részvételi döntéshozatal alkalmazása; a használatból és a helyi közösségekkel kötött közös gazdálkodási/kezelési megállapodásokból eredö haszon méltányos elosztása" (IPBES 2019a, b).

\section{Következtetések}

Közép- és Kelet-Európában sok magas természeti értékü ökoszisztéma - például majdnem minden réttípus, a legtöbb korábban vagy jelenleg is legeltetett gyep, valamint néhány nyílt erdő- és mocsártípus - aktív kezelést igényel ahhoz, hogy természeti értékei fennmaradjanak (Halada et al. 2011, Babai et al. 2014, Öllerer 2014, Varga et al. 2016a, 2017, Varga \& Molnár 2018, Biró et al. 2019). A hagyományos gazdálkodási módok - néhány szükségszerü módosítással - legtöbbször alkalmasak erre a természetvédelmi kezelésre (Fisher et al. 2012, Varga et al. 2016a, Biró et al. 2019).

A régió számos országában a hagyományos és helyi tudást, más néven hagyományos ökológiai tudást még mindig széles körben használják, különösen az alacsony mezőgazdasági potenciállal rendelkező marginális területeken, ahol egyébként gyakran a védett területek is találhatók (Roué \& Molnár 2017). Sok védett természeti területen az emberek még ma is aktívan gazdálkodnak, jószágot legeltetnek (Molnár 2012, Varga et al. 2016b). Az ilyen kultúrtájakban egyedi szabályozásra van szükség, hogy kulturálisan elfogadható, fenntartható és a biológiai sokféleség szempontjából a lehető legelőnyösebb használat és természetvédelmi célú kezelés valósulhasson meg. Ezek a szabályozások a természetvédelem és a helyi erőforrás-gazdálkodás közös érdekeire alapozhatók.

Régiónk számos országában és tájain a hagyományos gazdálkodás eltünőben van, de a hozzá kapcsolódó helyi és hagyományos ökológiai tudás a mai napig létezik a társadalmi emlékezet részeként (az idősebb generációk ökológiai emlékezete) (Molnár 2012a, b, c, Havel et al. 2016). Ezek az emlékek, megélt ta- 
pasztalatok rendkívül hasznosak lehetnek a helyi tájtörténet, a tájhasználat és az ökoszisztémák változásának rekonstruálásában és a megfelelő természetvédelmi gazdálkodási gyakorlat megtervezésében és kialakításában (Molnár et al. 2016, Varga et al. 2016b).

Régiónkban a hagyományos és helyi tudást gyakran nagy tisztelet övezi, régóta, sokan és sokat vizsgálják, és jól dokumentált, különösen a hagyományos kézmüvességhez, a népi gyógyászathoz kapcsolódó tudás vagy a népzene és a néptánc, a hagyományos szokások és ünnepek, ugyanakkor a hagyományos és helyi tudás ökológiai aspektusát, azaz az ún. hagyományos ökológiai tudást, sokkal kevésbé ismerik, tisztelik, vizsgálják és dokumentálják (Molnár et al. 2009). Sajnos az idő előrehaladtával egyre kevesebb lesz az e tudást aktívan használó, illetve a még élő ökológiai emlékezettel rendelkező ember. Ez csökkenti tájaink ökológiai ellenállóképességét (rezilienciáját) azáltal, hogy a természetvédelmi kezelés megtervezéshez és megvalósításához egyre kevesebb helyi, a biológiai sokféleséggel kapcsolatos információ áll majd rendelkezésre.

Végül reméljük, hogy az IPBES Globális Értékelő Tanulmánya, valamint Európa és Közép-Ázsia Értékelő Tanulmánya hozzájárul a helyi hagyományos tudás birtokosai, illetve tudásuk és tájhasználati módjaik magasabb szintű elismeréséhez, a tudomány és a helyi tudás jobb együttmúködéséhez, miközben segít a természeti és kulturális örökségünkkel való jobb gazdálkodásban, és mindezeken keresztül egy fenntarthatóbb jövő felé vezet.

Köszönetnyilvánitás - Az IPBES munkájában való magyar részvételt az NKFI Alap támogatta (IPBES 2.0 A további sikeres magyar részvétel biztosítása az Intergovernmental Platform on Biodiversity and Ecosystem Services munkájában (ED_18-1-2018-0003), illetve a 2015-2018 időszakra; A sikeres magyar részvétel biztosítása az Intergovernmental Platform on Biodiversity and Ecosystem Services (IPBES) munkájában (ED_15-1-20150007)). Öllerer Kingát az MTA Prémium posztdoktori pályázat támogatta.

\section{Irodalomjegyzék}

Agnoletti, M. (2006): Traditional knowledge and the European common agricultural policy (PAC): the case of the Italian national rural development plan 2007-2013. Cultural heritage and sustainable forest management: the role of traditional knowledge - Proceedings of the conference, 8-11. June 2006, Florence, Italy, IUFRO, Warsaw, Poland, pp. 17-25.

Babai, D., Molnár, Á. \& Molnár, Zs. (2014): “Ahogy gondozza, úgy veszi hasznát” Hagyományos ökológiai tudás és gazdálkodás Gyimesben. (Traditional ecological knowledge and land use in Gyimes (Eastern Carpathians). - MTA Bölcsészettudományi Kutatóközpont Néprajztudományi Intézet, MTA Ökológiai Kutatóközpont Ökológiai és Botanikai Intézet, Budapest, Vácrátót, 173 p. 
Babai, D., Tóth, A., Szentirmai, I., Biró, M., Máté, A., Demeter, L., Szépligeti, M., Varga, A., Molnár, Á., Kun, R. \& Molnár, Zs. (2015): Do conservation and agri-environmental regulations support effectively traditional small-scale farming in east-central European cultural landscapes? Biodivers. Conserv. 24: 3305-3327. https://dx.doi.org/10.1007/s10531-015-0971-z

Babai, D., Ulicsni, V., \& Avar, Á. (2017): Conflicts of economic and cultural origin between farmers and wild animal species in the Carpathian Basin — an ethnozoological approach. - Acta Ethnograph. Hung., 62: 187-206.

Biró, M., Molnár, Zs., Babai, D., Dénes, A., Fehér, A., Barta, S., Sáfián, L., Szabados, K., Kiš, A., Demeter, L. \& Öllerer, K. (2019): Reviewing historical traditional knowledge for innovative conservation management: A re-evaluation of wetland grazing. - Sci. Total Environ. 666: 1114-1125. https://dx.doi.org/10.1016/j.scitotenv.2019.02.292

Blicharska, M., Orlikowska, E. H., Roberge, J.-M. \& Grodzinska-Jurczak, M. (2016): Contribution of social science to large scale biodiversity conservation: A review of research about the Natura 2000 network. - Biol. Conserv. 199: 110-122. https://dx.doi.org/10.1016/j.biocon.2016.05.007

Bürgi, M., Gimmi, U. \& Stuber, M. (2013): Assessing traditional knowledge on forest uses to understand forest ecosystem dynamics. - For. Ecol. Manage. 289: 115-122. https://dx.doi. org/10.1016/j.foreco.2012.10.012

Carrus, G., Bonaiuto, M., \& Bonnes, M. (2005): Environmental concern, regional identity, and support for protected areas in Italy. - Environ. Behav. 37: 237-257. https://dx.doi. org/10.1177/0013916504269644

Demeter, L. (2017): Biodiversity and ecosystem services of hardwood floodplain forests: Past, present and future from the perspective of local communities in West Ukraine. - In: Roué, M. \& Molnár, Zs. (eds.): Knowing our Land and Resources: Indigenous and local knowledge of biodiversity and ecosystem services in Europe \& Central Asia. Knowledges of Nature 9. UNESCO, Paris, pp. 6-19.

Díaz, S., Pascual, U., Stenseke, M., Martín-López, B., Watson, R. T., Molnár, Zs., Hill, R., Chan, K. M. A., Baste, I., Brauman, K. A., Polasky, S. S., Church, A., Lonsdale, M., van Oudenhoven, A. P. E., van der Plaat, F., Schröter, M., Aumeeruddy-Thomas, Y., Bukyareva, E., Davies, K., Erpul, G., Failler, P., Guerra, C. A., Hewitt, C. L., Keune, H., Larigauderie, A., Lavorel, S., Leadley, P. W., Lindley, S., Demissew, S. \& Shirayama, Y. (2018): Assessing nature's contributions to people. Recognizing culture, and diverse sources of knowledge, can improve assessments. - Science 359 (6373): 270-272. https://dx.doi.org/10.1126/science.aap8826

Elbakidze, M., Angelstam, P., Sobolev, N., Degerman, E., Andersson, K., Axelsson, R. \& Wennberg, S. (2013): Protected area as an indicator of ecological sustainability? A century of development in Europe's boreal forest. - Ambio 42: 201-214. https://dx.doi.org/10.1007/s13280-012-0375-1

Elbakidze, M., Hahn, T., Zimmermann, N. E., Cudlín, P., Friberg, N., Genovesi, P., Guarino, R., Helm, A., Jonsson, B., Lengyel, S., Leroy, B., Luzzati, T., Milbau, A., Pérez-Ruzafa, A., Roche, P., Roy, H., Sabyrbekov, R., Vanbergen, A. \& Vandvik, V. (2018): Chapter 4: Direct and indirect drivers of change in biodiversity and nature's contributions to people. - In: Rounsevell, M., Fischer, M., Torre-Marin Rando, A. \& Mader, A. (eds.): The regional assessment report on biodiversity and ecosystem services for Europe and Central Asia. Secretariat of the Intergovernmental Science-Policy Platform on Biodiversity and Ecosystem Services, Bonn, pp. 385-568.

Fabók, V., Kovács, E., \& Kalóczkai, Á. (2015). Érintettek percepcióinak feltárása egy védett ragadozómadarakkal kapcsolatos konfliktusban a Jászság SPA részvételi tervezési folyamata során. - Termvéd Közlem. 21: 64-75.

Fernández-Giménez, M. E. \& Estaque, F. F. (2012): Pyrenean pastoralists’ ecological knowledge: documentation and application to natural resource management and adaptation. - Hum. Ecol. 40: 287-300. https://dx.doi.org/10.1007/s10745-012-9463-x 
Fischer, J., Hartel, T. \& Kuemmerle, T. (2012): Conservation policy in traditional farming landscapes. - Cons. Lett. 5: 167-175. https://dx.doi.org/10.1111/j.1755-263X.2012.00227.x

Garnett, S. T., Burgess, N. D., Fa, J. E., Fernández-Llamazares, Á., Molnár, Zs., Robinson, C. J., Watson, J. E. M., Zander, K. K., Austin, B., Brondizio, E. S., Collier, N. F., Duncan, T., Ellis, E., Geyle, H., Jackson, M. V., Jonas, H., Malmer, P., McGowan, B., Sivongxay, A. \& Leiper, I. (2018): A spatial overview of the global importance of Indigenous lands for conservation. $-\mathrm{Na}$ ture Sust. 1: 369-374. https://dx.doi.org/10.1038/s41893-018-0100-6

Grodzinska-Jurczak, M. \& Cent, J. (2011): Expansion of Nature Conservation Areas: Problems with Natura 2000 Implementation in Poland? - Environ. Manage. 47: 11-27. https://dx.doi. org/10.1007/s00267-010-9583-2

Gugič, G. (2009): Managing sustainability in conditions of change and unpredictability - The living landscape and floodplain ecosystem of the Central Sava River basin. - Lonjsko Polje Nature Park Public Service, Krapje, Croatia.

Halada, L., Evans, D., Romão, C. \& Petersen, J-E. (2011): Which habitats of European importance depend on agricultural practices? - Biodivers. Conserv. 20: 2365-2378. https://dx.doi. org/10.1007/s10531-011-9989-z

Havel, A., Molnár, Á., Ujházy N., Molnár, Zs. \& Biró, M. (2016): Zsiókások és nádasok legeltetése és egyéb használatai a Duna-völgyi szikes tavak területén a helyi emberek visszaemlékezései alapján. - Termvéd Közlem. 22: 84-95. https://dx.doi.org/10.20332/tvk-jnatconserv.2016.22.84

Hernández-Morcillo, M., Hoberg, j. Oteros-Rozas, E., Plieninger, T., Gómez-Baggethun, E. \& Reyes-García, V. (2014): Traditional ecological knowledge in Europe: status quo and insights for the environmental policy agenda. - Environment: Science and Policy for Sustainable Development 56: 3-17. https://dx.doi.org/10.1080/00139157.2014.861673

IPBES (2018a): Summary for policymakers of the regional assessment report on biodiversity and ecosystem services for Europe and Central Asia of the Intergovernmental Science-Policy Platform on Biodiversity and Ecosystem Services. Fischer, M., Rounsevell, M., Torre-Marin Rando, A., Mader, A., Church, A., Elbakidze, M., Elias, V., Hahn, T., Harrison, P. A., Hauck, J., MartínLópez, B., Ring, I., Sandström, C., Sousa Pinto, I., Visconti, P., Zimmermann N. E., \& Christie M. - Secretariat of the Intergovernmental Science-Policy Platform on Biodiversity and Ecosystem Services, Bonn, $48 \mathrm{p}$.

IPBES (2018b): The regional assessment report on biodiversity and ecosystem services for Europe and Central Asia. Rounsevell, M., Fischer, M., Torre-Marin Rando, A. \& Mader, A. (eds.). Secretariat of the Intergovernmental Science-Policy Platform on Biodiversity and Ecosystem Services, Bonn, $892 \mathrm{p}$.

IPBES (2019a): Summary for policymakers of the global assessment report on biodiversity and ecosystem services of the Intergovernmental Science-Policy Platform on Biodiversity and Ecosystem Services. Díaz, S., Settele, J., Brondízio, E., et al. - Secretariat of the Intergovernmental Science-Policy Platform on Biodiversity and Ecosystem Services, Bonn, 48 p.

IPBES (2019b): Global assessment report on biodiversity and ecosystem services of the Intergovernmental Science-Policy Platform on Biodiversity and Ecosystem Services. Brondízio, E., Settele, J., Díaz, S., Ngo, H. T. (szerk.). - Secretariat of the Intergovernmental Science-Policy Platform on Biodiversity and Ecosystem Services, Bonn, 892 p.

Juhász, E., Babai, D., Biró, M., Molnár, Zs. \& Ulicsni, V. (2017): Az eurázsiai hód (Castor fiber) táplálkozási és fásszárú-használati szokásaival kapcsolatos helyi tudás két évtizeddel a visszatelepítések kezdete után a Kárpát-medencében. - Termvéd Közlem. 23: 182-200. https://dx.doi. org/10.20332/tvk-jnatconserv.2017.23.182

Juler, C. (2014): După coada oilor: long-distance transhumance and its survival in Romania. - Pastoralism 4: 4. https://dx.doi.org/10.1186/2041-7136-4-4 
Kalóczkai, Á., Pataki, Gy., Kelemen, E., Kovács, E. \& Fabók, V. (2015): A földhasználati konfliktusok tényezői és dinamikája védett természeti területeken. - Termvéd Közlem. 21: 97-107.

Kelemen, E., Nguyen, G., Gomiero, T., Kovács, E., Choisis, J-P., Choisis, N., Paoletti, M., Podmaniczky, L., Ryschawy, J., Sarthou J-P., Herzog, F., Dennis, P. \& Balázs, K. (2013): Farmers' perceptions of biodiversity: lessons from a discourse-based deliberative valuation study. Land Use Policy 35: 318-328. https://dx.doi.org/10.1016/j.landusepol.2013.06.005

Kis, J., Barta, S., Elekes, L., Engi, L., Fegyer, T., Kecskeméti, J., Lajkó, L. \& Szabó, J. (2017): Traditional Herders' Knowledge and Worldview and Their Role in Managing Biodiversity and Ecosystem Services of Extensive Pastures. - In: Roué, M. \& Molnár, Zs. (eds.): Knowing Our Land and Resources: Indigenous and Local Knowledge of Biodiversity and Ecosystem Services in Europe \& Central Asia. Knowledges of Nature 9. UNESCO, Paris, pp. 57-71.

Kovács, E., Fabók, V., Kalóczkai, Á. \& Hansen, H. P. (2016): Towards understanding and resolving the conflict related to the Eastern Imperial Eagle (Aquila heliaca) conservation with participatory management planning. Land Use Policy, 54: 158-168.

Kovács, E., Kelemen, E., Kiss, G., Kalóczkai, Á., Fabók, V., Mihók, B., Megyesi, B., Pataki, Gy., Bodorkós, B., Balázs, B., Bela, Gy., Margóczi, K., Roboz, Á. \& Molnár, D. (2017). Evaluation of participatory planning: Lessons from Hungarian Natura 2000 management planning processes. J. Environ. Manage. 204: 540-550. https://dx.doi.org/10.1016/j.jenvman.2017.09.028

Lieskovský, J., Kenderessy, P., Špulerová, J., Lieskovský, T., Koleda, P., Kienast, F. \& Gimmi, U. (2014): Factors affecting the persistence of traditional agricultural landscapes in Slovakia during the collectivization of agriculture. - Landsc. Ecol. 29: 867-877. https://dx.doi.org/10.1007/ s10980-014-0023-1

Martín-López, B., Church, A., Başak Dessane, E., Berry, P., Chenu, C., Christie, M., Gerino, M., Keune, H., Osipova, E., Oteros-Rozas, E., Paillard, S., Rossberg, A. G., Schröter, M. \& van Oudenhoven, A. P. E. (2018): Chapter 2: Nature's contributions to people and quality of life. - In: Rounsevell, M., Fischer, M., Torre-Marin Rando, A. \& Mader, A. (eds.): The regional assessment report on biodiversity and ecosystem services for Europe and Central Asia. Secretariat of the Intergovernmental Science-Policy Platform on Biodiversity and Ecosystem Services, Bonn, pp. 57-185.

Mathevet, R., Thompson, J. D., Folke, C. \& Chapin, F. S. (2016): Protected areas and their surrounding territory: socioecological systems in the context of ecological solidarity. - Ecol. Appl. 26: 5-16. https://dx.doi.org/10.1890/14-0421

Meuret, M. \& Provenza, F. (eds.) (2014): The art \& science of shepherding - Tapping the wisdom of French herders. - Acres, Austin, Texas, 434 p.

Mihók, B., Biró, M., Molnár, Zs., Kovács, E., Bölöni, J., Erős, T., Standovár, T., Török, P., Csorba, G. \& Báldi, A. (2017): Biodiversity on the waves of history: conservation in a changing social and institutional environment in Hungary, a post-soviet EU member state. - Biol. Cons. 211: 67-75. https://dx.doi.org/10.1016/j.biocon.2017.05.00

Mihók, B., Kiss, G., Kovács, E., Margóczi, K., Fabók, V. \& Kalóczkai, Á. (2016): Ki mondja meg, mi a fontos? - Részvétel és természetvédelem. - Termvéd Közlem. 22: 131-154.

Molnár, Zs. (2011b): A hortobágyi pásztorok növényzetismerete. - Bot. Közlem. 98: 133-172.

Molnár, Zs. (2011a): Hortobágyi pásztorok hagyományos ökológiai tudása a legeltetésről, kaszálásról és ennek természetvédelmi vonatkozásai. - Termvéd Közlem. 17: 12-30.

Molnár, Zs. (2012a): A Hortobágy pásztorszemmel. A puszta növényvilága. - Hortobágy Természetvédelmi Közalapítvány, Debrecen, 160 p.

Molnár, Zs. (2012b): A Hortobágyi pásztorok növényosztályozása, a vadon termő növények ismertsége és néven nevezettsége. - Crisicum 7: 153-207. 
Molnár, Zs. (2012c): Hortobágyi pásztorok tájtörténeti és vegetációdinamikai ismeretei. - Bot. Közlem. 99: 103-119.

Molnár, Zs. (2015): „Kiszáradt a tóbúl mind a sár, mind a víz” - a Hortobágy, a szíkes puszta és a legeltetés a pásztor, az író, költő és a botanikus szemével. - In: Juhász, Z. (szerk.): Pásztormüvészet. Magyar Művészeti Akadémia, Budapest, pp. 27-80.

Molnár, Zs. (2018): A hagyományos ökológiai tudás szerepe a fenntarthatósági célok kapcsán. In: Fülöp, S. (szerk.): Országunk-világunk átalakitása. A fenntartható fejlödés terén 2030-ig megoldandó feladataink. Ökopolisz Alapítvány, Budapest, pp. 103-108.

Molnár, Zs., Bartha, S. \& Babai, D. (2008): Traditional ecological knowledge as a concept and data source for historical ecology, vegetation science and conservation biology: A Hungarian perspective. - In: Szabó, P. \& Hédl, R. (eds.): Human Nature. Studies in Historical Ecology and Environmental History. Institute of Botany of the ASCR, Brno, pp. 14-27.

Molnár, Zs., Bartha, S. \& Babai, D. (2009): A népi növényzetismeret és az etnogeobotanikai, ökológiai antropológiai megközelítés szerepe napjaink vegetáció- és tájkutatásában. - Bot. Közlem. 96: $95-116$.

Molnár, Zs. \& Berkes, F. (2018): Role of Traditional Ecological Knowledge in Linking Cultural and Natural Capital in Cultural Landscapes. - In: Paracchini, M. L. \& Zingari, P. (eds.): Reconnecting Natural and Cultural Capital - Contributions from Science and Policy. Office of Publications of the European Union, Brussels, pp. 183-194.

Molnár, Zs. \& Kovács, G. (2014): Egy pásztoroktól tanult élőhelytípus: a marikkal rakott főd a Hortobágyon, táji környezete, geomorfológiája, növényzete és madárvilága. - In: Tóth, A. (szerk.): A tájkutatás szolgálatában. 40 éves a Hortobágyi Természetvédelmi Kutatótábor. Geopont '95 Bt., Alföldkutatásért Alapítvány, Kisújszállás, pp. 201-223.

Molnár, Zs., Kis, J., Vadász, Cs., Papp, L., Sándor, I., Béres S., Sinka, G. \& Varga, A. (2016): Common and conflicting objectives and practices of herders and nature conservation managers: the need for a new profession, the "conservation herder". - Ecosyst. Health Sustain. 2: e01215. https://dx.doi.org/10.1002/ehs2.1215

Oteros-Rozas, E., Ontillera-Sánchez, R., Sanosa, P., Gómez-Baggethun, E., Reyes-García, V. \& González J. A. (2013): Traditional ecological knowledge among transhumant pastoralists in Mediterranean Spain. - Ecol. Soc. 18:33. https://dx.doi.org/10.5751/ES-05597-180333

Öllerer, K. (2014): The ground vegetation management of wood pastures in Romania - Insights in the past for conservation management in the future. Appl. Ecol. Env. Res. 12: 549-562. https:// doi.org/10.15666/aeer/1202 549562

Purvis, A., Molnár, Zs., Obura, D., Ichii, K., Willis, K. (2019): Status and trends - Nature (Chapter 2.2). - In: Brondízio, E., Settele, J., Díaz, S. \&Ngo, H. T. (eds.): Global assessment report on biodiversity and ecosystem services of the Intergovernmental Science-Policy Platform on Biodiversity and Ecosystem Services. Secretariat of the Intergovernmental Science-Policy Platform on Biodiversity and Ecosystem Services, Bonn.

Reyes-García, V., Fernández-Llamazares, A., McElwee, P., Molnár, Zs., Öllerer, K., Wilson, S. \& Brondízio E. (2019): The contributions of Indigenous Peoples and Local Communities to ecological restoration. - Restor. Ecol. 27: 3-8. https://dx.doi.org/10.1111/rec.12894

Rotherham, I. D. (2007): The implications of perceptions and cultural knowledge loss for the management of wooded landscapes: A UK case-study. - Forest Ecol. Manag. 249: 100-115. https:// dx.doi.org/10.1016/j.foreco.2007.05.030

Roué, M. \& Molnár, Zs. (eds.) (2017): Knowing our Land and Resources: Indigenous and local knowledge of biodiversity and ecosystem services in Europe \& Central Asia. - Knowledges of Nature 9. UNESCO, Paris, 148 p. 
Ulicsni, V., Babai, D., Vadász, Cs., Vadász-Besnyői, V., Báldi, A. \& Molnár, Zs. (2019): Bridging conservation science and traditional knowledge of wild animals: the need for expert guidance and inclusion of local knowledge holders. - Ambio 48: 769-778. https://dx.doi.org/10.1007/s13280018-1106-Z

Varga, A., Heim, A., Demeter, L. \& Molnár, Zs. (2016a): Rangers bridge the gap: integration of wood-pasture related traditional ecological knowledge into nature conservation. - In: Roué, M. \& Molnár, Zs. (eds.): Knowing our Land and Resources: Indigenous and local knowledge of biodiversity and ecosystem services in Europe \& Central Asia. Knowledges of Nature 9. UNESCO: Paris, pp. 78-91.

Varga, A. \& Molnár, Zs. (2018): Fás-erdős legeltetési rendszerek a magyar nyelvü néprajzi irodalom tükrében. - In: Gyuricza, Cs. \& Borovics, A. (szerk.): Agráerdészet. Nemzeti Agrárkutatási és Innovációs Központ, Szeged, pp. 93-114.

Varga, A., Molnár, Zs., Biró, M., Demeter, L., Gellény, K., Miókovics, E., Molnár, Á., Molnár, K., Ujházy, N., Ulicsni, V. \& Babai, D. (2016b): Changing year-round habitat use by extensively herded cattle, sheep and pigs in East-Central Europe between 1940 and 2014: Consequences for conservation management. - Agr. Ecosyst. Environ. 234: 142-153. https://dx.doi.org/10.1016/j. agee.2016.05.018

Varga, A., Samu, Z. T. \& Molnár, Zs. (2017): A fáslegelők és legelőerdők használata magyarországi pásztorok és gazdálkodók tudása alapján. - Termvéd Közlem. 23: 242-258. https://dx.doi. org/10.20332/tvk-jnatconserv.2017.23.242

Internetes hivatkozások:

http1: https://ipbes.okologia.mta.hu/ (utolsó csatlakozás: 2019. szeptember 10.) 


\title{
Traditional, indigenous and local knowledge in the Global, and the Europe and Central Asia Assessments of IPBES
}

\section{Zsolt Molnár ${ }^{1}$, Dániel Babai ${ }^{2}$, Anna Varga ${ }^{1}$, László Demeter ${ }^{1}$ and Kinga Öllerer ${ }^{1,3}$}

\author{
${ }^{1}$ MTA Centre for Ecological Research, Institute of Ecology and Botany, \\ H-2163 Vácrátót, Alkotmány u. 2-4., Hungary \\ ${ }^{2}$ MTA Research Centre for the Humanities, \\ H-1097 Budapest, Tóth Kálmán u. 4., Hungary \\ ${ }^{3}$ Institute of Biology Bucharest, Romanian Academy, \\ 060031 Bucharest, Spl. Independenței 296., Romania \\ E-mail:molnar.zsolt@okologia.mta.hu
}

The Global Assessment on Biodiversity and Ecosystem Services released in May 2019 by the United Nations' Intergovernmental Science-Policy Platform on Biodiversity and Ecosystem Services acknowledged that nature conservation could become more efficient with the inclusion of traditional, indigenous and local knowledge, and the participation of holders of these knowledges. This paper provides a summary of available evidence and key messages supporting this reasoning and recommendation. We collated original quotations (in italics) from the Summary for Policy Makers of the Global, and the Europe and Central Asia Assessments and from their background reports to show the conclusions authors have come up with after conducting reviews of the best available peer-reviewed and grey scientific and traditional knowledge literature. We also provide some regionally (Central and Eastern Europe) relevant context to these original texts.

Keywords: traditional ecological knowledge, traditional land-use, knowledge systems, knowledge co-production 